\title{
MATERNAL COMPLIANCE IN POSTPARTUM VISITS IN PULAU BULUH VILLAGE BULANG DISTRICT, BATAM CITY
}

\author{
Efilona Setri ${ }^{1}$, Mohd. Faisyal Reza ${ }^{2}$ \\ efilonasetri @ univbatam.ac.id ${ }^{1}$, mohdfaisyalreza@univbatam.ac.id ${ }^{2}$ \\ Medical Education Study Program, Faculty of Medicine, Batam University ${ }^{1}$ \\ Doctor's Professional Study Program, Faculty of Medicine, Batam University ${ }^{2}$ \\ Jl. Uniba No. 5, Batam Center
}

\begin{abstract}
Background : According to the World Health Organization (WHO), maternal mortality is still quite high, every day around the world around 800 women die from complications during pregnancy, childbirth and the puerperium. In 2013, 289,000 women died during and after pregnancy, childbirth and the puerperium. Between 1990 and 2013, the global maternal mortality rate (i.e. the number of maternal deaths per 100,000 live births) decreased by only $2.6 \%$ per year. This figure is still far from the target of reducing the annual MMR (5.5\%) needed to achieve the 5th MDG target (Andiani, and Retno, 2014).
\end{abstract}

Method : The research objective was to determine the compliance of mothers in conducting postpartum visits.

Result : Results of the Research on Maternal Compliance in Postpartum Visits Postpartum Visits in Pulau Buluh Village, Bulang District, Batam City It was found that maternal post-partum visits in Pulau Buluh Village consisted of 35 respondents, namely 19 respondents (54\%) postnatal visits were obedient, and 16 respondents $(46 \%)$ postpartum visits are non-compliant

Conclusion : It is known that $19(54 \%)$ of the respondent's frequency distribution of Compliance Postpartum visits are complete and $16(46 \%)$ respondents who are incomplete during postpartum visits

\section{Keywords: Compliance, Mother, Visits, Postpartum}

\section{INTRODUCTION}

The puerperium period is the period after childbirth that is needed for the recovery of uterine tools such as before pregnancy which lasts for 6 weeks. Complications during the puerperium are usually caused by an abnormal condition during the puerperium caused by the entry of germs into the genetalia during childbirth and the puerperium. The postpartum period is a prone period for mothers, around $60 \%$ of maternal deaths occur after childbirth and nearly $50 \%$ of deaths during childbirth occur in the first 24 hours after delivery, including due to complications during the puerperium, including bleeding (Saleha, 2009).

During the postpartum period, attention should be paid to reducing maternal and infant mortality rates in Indonesia. From various countries, most of the maternal deaths are during the postpartum period, therefore health experts recommend that first aid efforts be focused on the intrapartu period. During the postpartum period, at least 4 visits to the midwife must be made to find out the complications experienced during the postpartum period. Midwifery care carried out by midwives can affect the quality of care provided in services such as antenatal, intranatal, postnatal and newborn care (Saleha, 2009).

Bleeding during the puerperium (post partum hemorrhage) is bleeding that occurs after delivery of more than 500-600 ml within 24 hours after the child is born. There are 2 post partum hemorrhages, namely primary bleeding and secondary bleeding. The causes of primary and secondary bleeding include uterine atony, retained placenta, retained placenta or remaining placenta, laceration of the birth canal, uterine inversion, sub involution, puerperal infection (Ambarwati and Wulandari, 2010). 
This postpartum period is quite an important period for health workers, especially midwives, to always carry out monitoring because inadequate implementation can cause the mother to experience various problems, and can even lead to peurpeural sepsis. During the postpartum period, not a few mothers experience health problems. Culture and myths that are sometimes less beneficial to maternal health during the postpartum period are still problems that can even lead to maternal and infant deaths (Sulistyawati, 2009).

Here the midwife plays a very important role in providing solutions so that mothers understand in carrying out their new role as a mother, namely providing explanations to post partum mothers about postpartum visits or completeness of postpartum visits, providing explanations to post partum mothers about breast care, telling mothers how to breastfeed good and right babies, teaches how to care for babies that are good and right (Ambarawati, 2009).

According to national policy, postpartum visits are carried out at least four times, namely 6-8 hours after delivery, six days after delivery, two weeks after delivery, six weeks after delivery. This visit aims to assess the status of mothers and newborns as well as to prevent, detect, and deal with problems that occur. Midwives have a very important role in this period through health education, monitoring, and early detection of childbirth hazards. During the postpartum period, the mother will experience various changes. Service or care is an important way of monitoring and supporting the health of normal postpartum mothers and knowing early if any irregularities are found with the aim that the mother can safely go through the postpartum period (Saleha, 2009).

According to the World Health Organization (WHO), maternal mortality is still quite high, every day around the world around 800 women die from complications during pregnancy, childbirth and the puerperium. In 2013, 289,000 women died during and after pregnancy, childbirth and the puerperium. Between 1990 and 2013, the global maternal mortality rate (i.e. the number of maternal deaths per 100,000 live births) decreased by only $2.6 \%$ per year. This figure is still far from the target of reducing the annual MMR (5.5\%) needed to achieve the 5th MDG target (Andiani, and Retno, 2014).
Based on the 2012 IDHS, the maternal mortality rate (MMR) is very surprising. Maternal mortality jumped very significantly to 359 per 100,000 live births or returned to the condition in 1997. This means that maternal health has actually deteriorated for 15 years. In 2007, MMR in Indonesia actually reached 228 per 100,000 live births. Sadly, this very high MMR means that Indonesia is even worse than the poorest countries in Asia, such as Timor Leste, Myanmar, Bangladesh and Cambodia. Indonesia has now been predicated on the backward in Asia in protecting maternal health. This maternal mortality emergency must end with serious improvements in policies, budgets and immediate action (Menkes, 2013).

Data from the Batam city health office during 2013 the lowest number of postpartum visits was the Bulang health center area $(52 \%)$, (Batam Health Office, 2014). According to data on postpartum service reports at the Bulang Puskesmas, Buluh Island Village, 2013 shows that the coverage of postpartum care is $76 \%$, while in 2014 it was reported as much as $77 \%$, so it can be concluded that there has been an increase in the coverage of postpartum services. While the target of postpartum services at Bulang Puskesmas is $85 \%$, this still shows the lack of postpartum service coverage from the target (Puskesmas Bulang, 2014)

The research objective was to determine the compliance of mothers in conducting postpartum visits

\section{RESEARCH METHODS}

The design that researchers use is a descriptive design that aims to find out the picture. The place of this research was conducted in Pulau Buluh Village, Bulang District, Batam City. Population is a generalization area consisting of objects / subjects that have certain quantities and characteristics set by researchers to study and then draw conclusions (Setiawan 2010 in Ariani, 2014). Where the population in this study were 35 postpartum mothers in Pulau Buluh Village. The sampling of this study used a total sampling technique, namely the technique of determining the sample when all members of the population were used as samples (Setiawan, 2010 in Ariani, 2014). Thus, the researchers took a sample of 35 postpartum mothers in Buluh Village. The tool used in this research is a questionnaire containing questions that are structured 
according to the research objectives. Univariate analysis aims to explain or describe the characteristics of each research variable. The form of univariate analysis depends on the type of data. For numerical data, the mean or mean, median and standard deviation is used

\section{RESEARCH RESULT}

Buluh Island sub-district has a population of 2,657 people in 689 families (KK), this subdistrict has 3 community associations (RW) and 11 neighborhood associations (RT), and the Puskesmas itself is located in Pulau Buluh Village, the program of the postpartum program is to conduct postpartum visits. 4 times during the postpartum period, namely the first visit (KF1) 6-8 hours after delivery, the second visit at (KF2) 6 days after delivery, the third visit (KF3) 2 weeks after delivery, the fourth visit (KF4) 6 weeks after delivery Every month health workers provide counseling about all health problems to cadres, community leaders and all communities on Buluh Island. To obtain services according to standards by conducting data assessments which include: identity / bio data, pregnancy history, obstetric history, medical history, postpartum examination, health services, counseling and consultation as well as providing services. Maternal Compliance in Post-Postnatal Visits Post-natal Visits in Pulau Buluh Village, Bulang District, Batam City

It was found that the postpartum visits of the mother in the Pulau Buluh Village which consisted of 35 respondents, namely 19 respondents $(54 \%)$ the postpartum visits were obedient, and 16 respondents $(46 \%)$ the postpartum visits were not obedient.

\section{DISCUSSION}

From the results of the univariate analysis, it was found that there were 19 respondents (54\%) who were complete during the postpartum visit (54\%), while 16 respondents (46\%) did not comply.

According to (Green in Notoatmodjo, 2003), compliance is a change in behavior from behavior that does not obey the rules to behavior that obeys the rules. One of the factors of obedience is education. According to (Notoatmodjo, 2003), education is an activity, a human effort to improve personality or the process of changing behavior towards maturity and perfecting human life by fostering and developing the potential of his personality, which is in the form of spiritual (creativity, taste, intention) and body.

Based on research conducted by Muflikhatul, (2013) on "The Relationship between Postpartum Knowledge and Compliance with Postpartum Visits at Bpm Ny. Subiyanah, Sst Parengan Village, Madura District, Lamongan Regency in 2013 ". The results of this study indicate that most of the postpartum mothers were obedient to have postpartum visits $(66.7 \%)$ and almost part of the post-partum mothers who were not compliant had post-partum visits $(33.3 \%)$.

Based on the conclusions of the research results regarding postpartum visits in Buluh Island, Bulang Subdistrict, there were more obedience in postnatal visits than those who were not obedient in making postnatal visits. This can be influenced by educational factors. The majority of maternal education is high school as much as $63 \%$ because high education can improve the personality of the post-partum mother or the process of changing behavior from being disobedient to being obedient in conducting postnatal visits and assisted by health workers who are willing to provide information or counseling related to health, especially during visits childbirth.

\section{CONCLUSION}

It is known that 19 (54\%) of the respondent's frequency distribution of Compliance Postpartum visits are complete and 16 (46\%) respondents who are incomplete during postpartum visits

\section{SUGGESTION}

For Respondents

It is hoped that the community, especially postpartum mothers who have just given birth after getting knowledge about the importance of postpartum visits, will be able to know and apply the importance of conducting postpartum visits and to participate in activities held by health workers, such as counseling.

\section{BIBLIOGRAPHY}

Ambarawati, Retno Eny dan Wulandaridiah. 2009. AsuhanKebidanan Nifas. Jakarta : Mitra Cendikia Offset 
Arikunto, 2006. Prosedur Penelitian Suatu Pendekatan Praktek, Jakarta : Rineka Cipta

Arriani, 2014. Aplikasi Metodelogi Penelitian Kebidanan dan Kesehatan Reproduksi. Yogyakarta

Data Profil Kesehatan Kota Batam 2013 Angka Kematian Ibu

Data Profil Kesehatan Kota Batam 2013 Cakupan Kunjungan Nifas

Depkes. RI. 2012. Angka Kematian Ibu. Jakarta

Dinkes Kota Batam. 2013. Profil Kesehatan Kota Batam. Batam : Dinkes Kota Batam

Friedman, Marilyn M. 2010. Buku Ajar Keperawatan Keluarga: Riset Teori dan Praktek. Jakarta: EGC

Menkes.2013. Membedah Angka Kematian Ibu : Penyebab dan Akar Masalah Tingginya Angka Kematian Ibu. Jakarta Selatan

Notoatmodjo, Soekidjo. 2010. Metode Penelitian Kesehatan. Jakarta : Rineka Cipta

.2012. PromosiKesehatan dan Perilaku Masyarakat. Jakarta: Rineka Cipta

Prawiharjo, Sarwono 2011. Ilmu Kebidanan. Jakarta : PT Bina Pustaka

Rumengan, Jemmy.2008. Metode Penelitian Kesehatan. Bandung : Citapustaka Media Perintis

Rumengan, Jemmy.2008. Metode Penelitian . Bandung : Citapustaka Media Perintis

Saleha, Siti. 2009. Asuhan Kebinanan Pda Masa Nifas. Jakarta : Salemba Medika

Sulistyawati, Ari. 2009. Buku ajar Asuhan Kebinanan Ibu Nifaas. Yogyakarta : CV. Andi Offset

Suprajitno. 2014. Asuhan Keperawatan Keluarga: Aplikasi Dalam Praktik. Jakarta: EGC

Walyani dan Purwoastuti, 2015. Asuhan Kebidanan Masa Nifas dan Menyusui. Yogyakarta : PT Pustaka Baru

Fatimah, Siti. 2009. Hubungan Dukungan Suami Dengan Kejadian Postpartum Blues Pada ibu primipara Diruangan Bugenvile RSUD Tugurejo Semarang.

Sari, Jayanta. 2010. Hubungan Dukungan Suami Dengan Lama Persalinan Kala II di RB An Nissa. Surakaarta

Astuti, Asih. 2014. Hubungan Pengetahuan Ibu Tentang Kunjungan Nifas Dengan Kelangkapan Dalam Melakukan
Kunjungan Diwilayah Kerja Puskesmas Botania. Batam.

Hasanah dkk. 2013. Hubungan Dukungan Suami Dengan Frekuensi Kunjungan Ulang Nifas Di Wilayah Puskesmas Purwoyoso Kota Semarang.

Andianii,

Retno.2014,http://Retnooandianii.blogsp ot.com diperoleh tanggal 20 maret

KEPRI, tahun 2011,http//www.haluan kepri.com, diperoleh tanggal 11 Maret 2015

SKDI, tahun 2012, http : //.www.health detik.com, diperoleh tanggal 11 Maret 2015

Sackarpu. 2011. http://www.survey AKI dan AKB di Indonesia.com. Senin, 19 Maret 2012. 10.30 